\title{
Eschato-praxis and accountability: A study of Neo-African Pentecostal movement in the light of prosperity gospel
}

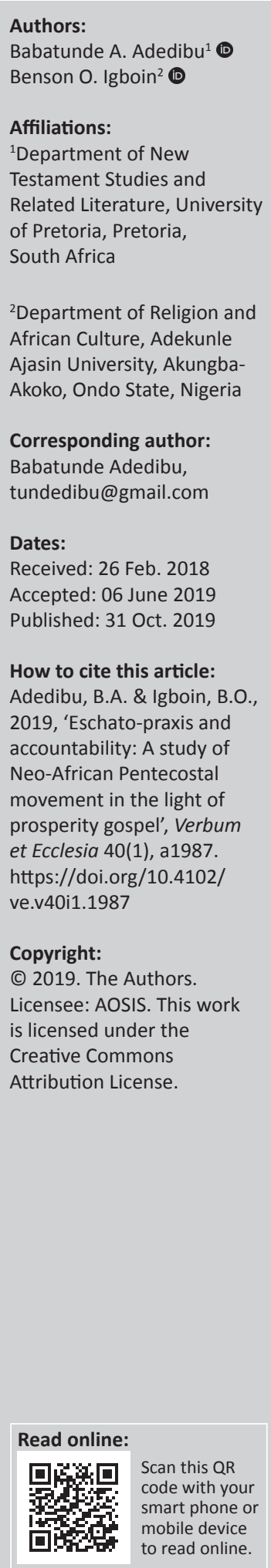

The quest for accountability in Christian theology is both immediate and ultimate. This, thus, suggests that individuals and groups within spiritual and secular spaces subscribe to some form of immediate and ultimate probity and accountability assessment. Given this, it would be argued that accountability has eschatological implications on neo-African Pentecostalism - the thrust of this study. Through the gristmill of eschato-praxis - a theory and belief that paradisiac bliss can be enjoyed on earth by Christians as a foretaste of its full and eternal enjoyment in heaven, a practice that has suffused neo-African Pentecostalism, which is largely manifest in luxury and quest for materiality - it would be argued why and how accountability must be countenanced into the practice of the neo-African Pentecostals, also as a foretaste of the ultimate demand and event. This study utilises descriptive and theological approaches to eschato-praxis and accountability within the neo-African Pentecostal movement.

Intradisciplinary and/or interdisciplinary implications: This article is interdisciplinary in that it presents an ethical perspective in terms of accountability with respect to the African Pentecostalism through the gristmill of eschato-praxis theory which is situated within the New Testament studies. This study argues that accountability and probity have eschatological implications on African Pentecostalism.

Keywords: life and death matters; African Pentecostalism; eschato-praxis; accountability; eschatological implications.

\section{Introduction}

One of the problems militating against the development of Africa has been identified as corruption, especially as it manifests in lack of accountability by its leadership. This has been a critical concern of classical Pentecostalism, which teaches and mostly practises holiness, a doctrine it believes countenances human accountability before God and humanity. While classical African Pentecostalism emphasises holiness or sanctification, it reminds its members that they should live as people who will ultimately give account to God. Thus, classical Pentecostalism teaches that while human beings live on earth, death also matters as death is not the end of life. Classical Pentecostalism refers to Hebrews 9: 27 to bring to the fore the importance of life and death matters, which we shall conceptualise below, as part of eschatological teaching. This teaching instils and also requires behavioural pattern and moral actions that demonstrate that members are accountable to the leadership of the church and God (Igboin 2018a, 2018b).

But many of the neo-Pentecostal churches have shifted their attention from holiness teaching to materialism, emphasising that the bliss of heaven could be enjoyed on earth as part of God's blessing on them. It thus increasingly appears that accountability and ultimacy are treated with less vigour than classical Pentecostalism. Neo-Pentecostal eschato-praxis emphasises the importance of life over death, and thus gives the impression that eschatology must be understood more as part of life rather than accountability before God ultimately.

We argue that life and death matter with regard to eschatology, and that eschato-praxis as taught and practised by neo-Pentecostal churches does not necessarily vitiate it. Eschatology as theological discourse takes serious interest in accountability. It is argued that accountability relates to both life and death. 


\section{Conceptualising life and death matter}

Wall's concept of theology is 'about doing things, about things that deeply affect the lives of a number of people. We see something of this already in South African Black Theology, which is literally about life and death matters' (Walls in Gittins 2000:13). Taking a cue from Wall, we can argue that life matters, death matters and there are matters of life and death. We can also say that there are life and death matters or life and death matter. All of these literal forms do not connote the same nuances and are not meant to, but they all matter because of the reality of accountability. One theological connotation Gittins conveys is that (Gittins 2000):

[L]ife matters, and death matters; indeed it is because life and death matter, that [eschatology] is such an important concern ... Whatever our attitude may be, it is always the case that life and death matter in their ordinariness and predictability, just as much - so our faith reminds is - as the more dramatic and unpredictable 'matters of life and death'. (p. 13)

Practically, life and death matters would mean struggles that people involve in to the extent that they are ready to pay the supreme price. There are such serious situations that people willingly give whatever it takes to get or break through to survive. Life and death matters would mean that there is no giving up and bowing to intimidation or circumstances that ordinarily one believes are insurmountable. It is indeed 'a door-die matter'; 'no retreat, no surrender'. It is an uncompromising struggle to have a breakthrough; a spirit that refuses to be undermined or suppressed epitomises rugged commitment to a lifestyle liberty. It is that spirit that defined the struggle of Africans against the colonial regime - a demand for humanity, justice and probity, accountability and above all independence. It is a life and death struggle: there is the full consciousness of the immediate and ultimate implications of acting in a certain way rather than the other. It is action based on responsibility and its consequences whichever way they come eventually. But not to act is completely out of it.

We adopt life matters and death matters in the context of our arguments here as they relate to eschato-praxis and accountability. In thinking this way, we argue that how a person lives matters so much that it has critical ways of affecting the judgement he or she would receive after life, that is, at death. Death matters because life for the believer is the ultimate; death is a passage to kind of eternity - life beyond physical death. Thus, life and death matter because they both mean much in a Christian's final destination. It is thus important to live well and to die well. The thrust here is normative; normative in the sense that living and dying well depend on certain ethical and moral rules, humanly observed but with ultimate concern. In his 'Doing things on earth for heaven's sake', Adogame (2014) argues, for instance, that African Pentecostal churches have contributed immensely to economic growth of Africa through their investment in education, media, publishing and banking, among others, which provide streams of employment and opportunities to the teeming population. Such investments cannot just be considered as mere socio-economic interventions; they must also be reckoned from the ultimate ethical point of view. Adogame makes the point that these socio-economic interventions cannot be divorced from issues of social capital, and thus accountability.

That is why critics of Christian investments have been very caustic comparing them with secular investments (Adedibu 2018:148-160). In other words, normative issues are raised when Christians and their investments either do not conform to standard or are exorbitant. For instance, some have argued that it is questionable that Christian or missionary universities in some countries in Africa charge exorbitant fees, often higher than those charged by public universities. When students in these universities misbehave, the public is quick to demand for Christian-based explanations that are in tandem with the biblical teaching without countenancing the host communities sociopolitical and cultural context from which the students come were raised. The press clearly wants a different, in fact, higher form of standard from the Christians, and by its criticisms, the critics are invariably calling for accountability and probity. To go literal and theological with Adogame's position, some African Pentecostals' activities should reflect eschatological demands, recalling and conforming to heaven's standard because of the immediate and ultimate consequences. In any case, we must appreciate the fact that the Christian activities in this regard are geared towards bettering a world that Christians believe can be bettered by their intervention, especially in Africa where there is an obvious failure of the state. But the manner in which many African neo-Pentecostal churches execute these interventions and the theological discourse it raises particularly concerning eschato-praxis requires some critique.

\section{Engaging eschato-praxis as a concept}

Eschato-praxis, as Braaten underscores it, is bringing the future back to the present. According to him (Braaten 2000:121):

$[I] \mathrm{n}$ proleptic ethics it may truly be said that the end justifies the means, because the end is proleptically present and operative beforehand, rehearsing the qualities of the eschatological kingdom-peace, love, joy, freedom, equality, unity - in the course of history's forward movement. (p. 121)

Braaten believes that the Christian can, and indeed must, engage in actions that will change the world into a better place. That is why Peters (2000:379) succinctly captures Braaten's eschato-praxis as 'doing the future ahead of time'. The 'doing' is an active intervention in the state of things in the present world: it is not an idle waiting for the manifestation of the eschatology. Christians, Peters agrees with Braaten, must be involved because (Peters 2000):

$[N]$ ot only does eschatology stimulate action; it is the very foundation of ethics. Once we apprehend God's will for the 
consummate future, we seek to incarnate that future proleptically in present human action. (p. 379)

This might have given vent to liberation theology where sociopolitical actions are encouraged and instituted in the here and now to ensure that the structure of evil and its oppressive consequences are actively engaged (Chimhanda, Molobi \& Itumeleng 2015; Cone 1970; Eagleson \& Drury 1975; Gutierrez 1973; Segundo 1975). De Gruchy (2002) argues thus:

Christian eschatology, the doctrine of the 'last things', is not simply about hope for justice in the future but about the impact which God's future has on our present experience. The Marxist critique was quite right in calling the bluff on the way in which eschatology was used to keep the poor in their place with promises of eternal reward. Though, paradoxically, in the history of the struggles of the poor and oppressed it has often been the case that the 'more other-worldly the focus ... the more thisworldly its relevance. The more we are able to trust God finally to transform the situation, the more we are lifted out of the mire of despair and set free to launch small-scale initiatives of resistance'. (p. 210)

Eschatology is indeed beyond such pragmatic actions against the 'Antichrist', that is, 'the self-contained system of institutionalized domination and exploitation, generating its own self-justifying norms, and living off the blood of the poor and the dispossessed' (Martin 2019:7) to ethics and responsibility that will ultimately result in accountability, not before man but God. 'As eschatological horizon the reign of God is the absolute principle of Christian ethics, which is the measure of all historical undertakings reformist and revolutionary included', as observed by Dussel (1988:15-16). Wittgenstein (Martin 2019:9) argues that ethics is supernatural despite the criticisms or objections that can be raised against it. It places on humanity a demand to live or act in one way rather than the other. In acting in a chosen manner, it must be underscored that the choice and action are not value-free; they point to a destination where full responsibility will be taken for them. Levinas (1969) further argued that:

Eschatology institutes a relation with being beyond the totality or beyond history, and not with being beyond the past and the present ... The eschatological as the 'beyond' of history, draws beings out of the jurisdiction of history and the future; it arouses them in and calls them forth to their full responsibility. (pp. 22-23)

Levinas adds that such responsibility is not an abstract concept that requires rationality to understand. On the contrary, it is one that is borne out of a relationship with God that melts the heart of man and woman, which should reflect in relational dynamics of people in a community. Levinas (1988) posits that:

The exposition of the ethical signification of transcendence and of the Infinite beyond being can be worked out beginning with the proximity of the neighbor and my responsibility for the other ... It consisted in being struck by the ' $i n^{\prime}$ ' of infinity which devastates presence and awakens subjectivity to the proximity of the other. (p. 166)
Kant (1956) also argues in this regard of 'being struck' by the transcendence that results in the awareness of ethics and responsibility. He talks about an encounter with a boundless magnitude of worlds beyond the worlds which did not only strike him with wonder, awe and astonishment but much more with new responsibility and ethical demand. Kant is awakened to the moral law within in the midst of the boundlessness of the worlds without. This brings Kant to the consciousness of his existence: existence demands responsibility and accountability, hence the realisation of the moral law within. Kant (1956) further asserted that:

Two things fill the mind with ever new and increasing admiration and awe, the oftener and more steadily we reflect on them: the starry heavens above me and the moral law within me. I do not merely conjecture them and seek them as though obscured in darkness or in the transcendent region beyond my horizon: I see them before me, and I associate them directly with the consciousness of my own existence. (p. 47)

According to Martin (2019:8), James Fowler argued that the Christian faith is reckoned with partly in the 'futurity of being', which is 'reflected in Jesus' teachings of the coming of the Kingdom of God, of the eschatological character of the Kingdom of God'. Cooper (2017:45) highlights how Erik Peterson's 'eschatological proviso' explains the nature of the Church or Christians' active participation in this Kingdom, that is, an eschatological praxis. This participation presupposes that the Kingdom of God is at once 'already' and 'not yet'. The punch of this argument is that the world will one day come to an end - history is moving towards this end. However, within the continental philosophy and theology, this seems to be a weak or poor theology, a hermeneutics of eschatology that emphasises a messiah rather than messianism, which pushes for a paradox and tension of the 'already-not-yet' or 'a mode of making the future a present but unfinished reality' (Sands 2017:2). Of course, it is this already-not-yet that keeps the Christian hope alive for a better place, a blissful place beyond this place in the here and now; a hope with responsibility with the consciousness of accountability in the Parousia. It is within this framework that the idea of 'Anticipation' (Sands 2017:5) in eschatological discourse makes more sense to the Christian. The idea or concept of 'Anticipation' is critical and instructive because, as Sands argues, it brings with it 'the eschatological promise of the impossible becoming possible or an end to history have become motivating principles behind understanding foundational intuitions and concepts within society' (Sands 2017:1). It will mean then that eschatology imposes responsibility - action consciously undertaken with the mind of rendering account to God at some time in the future. Hebert (n.d.) indeed advocates that the already-butyet hermeneutics of eschatology must be acted upon by the Church in reaching out to those who are yet outside the Kingdom of God with the full consciousness of the end of history that is about to break on the world.

What we have tried to underscore here is that although there are different sides to the understanding of eschatology, there 
are some irreducible contents that mean so much for the Christian - the idea of a God who, at the end of history, will reveal himself more perfectly though experienced partially now; the awareness that our existence places on us responsibility guided by some form of supernatural ethics; our participation in the history that is about to wind up and the hope for the future to fully come, though we participate in it partially now. Given this, we hope now to argue that eschato-praxis in some neo-Pentecostal churches does not seem to adequately countenance responsibility and ultimate accountability into its prosperity 'theology', a theology that seems not to hope for the realisation of eschatology - the end of history. We will explain that eschato-praxis implies enjoying eternal bliss on earth, devoid of 'anticipation' of heaven. But before then, it will be to engage the concept of accountability from theological and ethical perspectives through the lens of eschatology.

\section{Accountability in theological- eschatological prism}

The concept of accountability has attracted many interests in scholarship. Many have queried whether accountability should be understood as answerability and/or responsibility. They have also added whether irrational, non-rational or emotional actions should be accounted for. Shoemaker (2011) has attempted to differentiate between accountability and answerability in this submission:

To be answerable ... is to be susceptible for assessment of, and response to, the reasons one takes to justify one's actions. The sorts of answers one gives will reveal one's ends, the things one takes to be important, and so the concomitant responses may take the form of aretaic appraisals (predications attaching to one's character qua deliberator and tracker of reasons) or (mere) modification of attitudes and dispositions regarding future interactions. To be accountable, on the other hand, is to be susceptible to being held to account if one flouts relationshipdefining demands. (p. 603)

Shoemaker has raised both philosophical and ethical conceptualisations of the concepts of accountability and answerability. The point is to interrogate whether these two concepts are indeed different. This interrogation is important because more often than not, theologians and Christians generally tend to use them interchangeably.

From the point of view of Shoemaker, answerability involves actions that a person disposes and is held responsible for but which does not attract sanction. On the contrary, accountability relates to actions a person does, for which he or she is punished if it is evaluated to have violated moral principles. Smith, however, disagrees with Shoemaker that accountability can be neatly distinguished from answerability. In substantiating her objection, Smith (2012) argues that there is extant moral responsibility required from individuals against which their actions are evaluated. For instance, no one can rightly be called to account for his or her colour or race. But the expression of racism in the midst of multiracial people is a moral action that can be evaluated and then sanctioned. If racism is what Shoemaker points to as answerability, it is attributed, but being racist, as Smith argues, is a moral expression. Smith (2012) will then argue that we cannot be called to question for our physical nature, for example, being a short man, but what we do with our nature is a moral expression for which we can be called to answer for when evaluated. Thus, Smith concludes that there is no convincing argument that separates answerability from accountability. We are persuaded more by Smith's position because whenever someone is called to answer for his or her action, that action is evaluated. The decision to sanction is at the discretion of the superior or other prevailing circumstances and laws. Thus, we will understand accountability and answerability as a call evaluate actions one has disposed.

De Gruchy's nuances are also helpful in understanding theological notions of accountability. De Gruchy (2002:98) asserts that 'acknowledging accountability for faults and dealing with alienation and estrangement is fundamental to the creation of a reconciled and reconciling community'. This, he argues, is predicated on the realisation of the fact that one has erred or sinned. Although confession and penance are demanded as a function of accountability, they are geared to justice and peace. Thus, both the individual and the church need to recognise their guilt and be accountable for their actions within the community. Thus, De Gruchy (2002) further noted that:

[W] need to recognize that the pendulum has swung, and that what we now need is to recover a healthy sense of shame and guilt in order to regain a sense of moral responsibility and accountability. If sin means that we have done wrong; guilt means that we recognize that we are responsible for having done so, and deserve to be punished. (p. 192)

Despite the gratuitousness of forgiveness when genuinely offered, the ultimacy of judgement cannot be underplayed. De Gruchy (2002:202) further avers that, 'there can be no perfect justice unless we think in eschatological terms about the ultimate reign of God's righteousness'. He adds (De Gruchy 2002):

The recognition that there can never be perfect justice in this world no matter how much we seek to redress past injustices, explains in part the biblical expectation of a 'last judgement'. (p. 208)

Having said that, responsibility and accountability in theological-eschatological will refer to the ultimate judgement that every Christian must face at the Parousia. The concept of judgement, bema, has a Greek origin in the ancient Olympic games. At the end of the games, winners appeared before the bema seat to receive reward or trophies in accordance with their individual performance during the competitions. Thus, the understanding of the bema beat is reflective of the biblical judgement seat where Christians who had led a worthy or godly life would appear before God to receive crowns. In this sense, those who appear here would only receive rewards for their earthly life, and not condemnation. For as Paul argues, there is no more condemnation for those in Christ ( $\mathrm{Rm} \mathrm{8:1).}$ This will imply that the issues of salvation and sin at the bema 
seat (Rv 20:11-15). Those who would appear before the white throne judgement would be condemned.

The next section of this article considers the dynamics of prosperity gospel within African neo-Pentecostal movement and possible infraction with respect to the disposition of its adherents and leadership.

\section{Neo-African Pentecostalism and prosperity gospel}

Pentecostalism since its emergence has redefined the global Christian landscape. The movement perhaps might be described as the fastest growing tradition of the Christian faith. Previous scholarship noted that the global membership of the Pentecostal movement is estimated to be about 683 million adherents in 2018, about a quarter of the world's Christians, a figure predicted to rise to 796 million by 2025 . The geometric growth rate of this movement was evident as at 1970, when the membership was estimated to be about 63 million (Johnson et al. 2017:24). The growth of the Pentecostal movement, particularly from the Global South, is de-territorised as many of these churches are in North America and Western Europe, which used to be major heartlands of mission to the Global South, particularly Africa. They can be divided historically into four very broad, often overlapping groups: (1) 'Classical' Pentecostals with origins near the beginning of the 20th century and (2) Independent Pentecostal churches from early $20 \mathrm{~h}$ century, especially those in Africa and Asia. But in the statistics so frequently quoted, the term also includes: (3) 'Charismatics' in older churches from the 1960s onwards; (4) Independent Charismatic megachurches and neo-Charismatics/neo-Pentecostals that commenced in the mid-1970s, which are noted for their 'prosperity gospel', are the most controversial globally. Although some of the leaders of this movement in different parts of the world over time have been observed to be involved in various moral and financial misdemeanours, yet many of these churches in the Global South are actively involved in addressing social, economic and educational inequalities in their contexts.

Sub-African religioscape despite its pluralistic nature has witnessed remarkable presence and proliferation of neoPentecostal churches mostly in urban cities. The growth and proliferation of the Pentecostal movement, particularly the neo-Pentecostal brand in Africa, were accentuated by the moral corruption and leadership ineptitude of many African countries because of their inability to address the social and economic challenges of their citizens. Because of fading hope and increasing existential realities of many Africans, the neo-Pentecostal messages of hope provided succour for many Africans. It, thus, implies that the social deprivation theory is appropriate in describing one of the reasons of the proliferation of this brand of Christianity.

The changes in the religioscape with the proliferation of Pentecostalism in Africa is reflective of the global kaleidoscope as the 21st century has witnessed remarkable proliferation of the movement, particularly in the Global South or the nonWestern world, notably Asia, Latin America and Africa. Asamoah-Gyadu (2013) noted that the growth of pneumatic Christianity (African Pentecostalism and Charismatic) is because of:

[E]mphasis on personal transformation wrought by the Holy Spirit; its emphasis on the experience of the Holy Spirit with specific manifestation that make worship both heartfelt and body felt experience and the interventionist nature of charismatic [Pentecostal] theology, which is seen in healing, deliverance and prayers and prayer for breakthroughs in life. (p. 7)

This sums up the ritual, religious and liturgical subscription and the centrality of charismata in the theological position of Pentecostals in addressing existential challenges of its adherents, particularly in Africa. Furthermore, Jenkins (2006:12) posits that Pentecostals, including African Pentecostals, lay a strong emphasis on charismata (gifts of the Holy Spirit) and often apply a prophetic or literal exegesis into a scriptural text. Moreover, most neo-African Pentecostals tend to read prophetic meanings and interpretations to scriptures. Interestingly, the proliferation of neo-African Pentecostalism in Africa and its diaspora is hinged on the democratisation of Christianity, 'hence the mystery of the gospel would no longer be reversed for a secret privileged and educated few, but would be revealed to whoever was willing to receive it' (Anderson 1999:24).

As fledging as the Pentecostal movement's success in the redefinition of the Christian tradition across the global religiospace is, one of the most criticised doctrinal positions is the prosperity gospel. Quoting Coleman, Gbote and Kgatla (2014:2) describe prosperity gospel as the 'accumulation of wealth and good health based on one's good work or giving power to the church'. Jones and Woodbridge (2011:27) traced the origin of prosperity gospel to the 'New Thought Movement', in 1855. The New Thought Movement believes in the power of positive thinking and confession, which they claim can lead to the actualisation of one's aspiration. However, Platt (2010:10) affirms that prosperity gospel is associated with the American dream in which materialism is understood as the primary source of well-being, although this inevitably has led to consumerism, which is the 'excessive, even pathological preoccupation with consumption'.

Indeed, the nuances of the prosperity gospel resonate within the traditional African religions because of the belief in mystical causality. From the African traditional perspective, these churches constitute sacred spaces where rituals, prayers and liturgical practices are offered to enhance or transform the destinies of their adherents or reveal the solutions to their existential challenges which are common within the sacred spaces of African traditional practices (Adedibu 2013:111). In the African traditional religious space, the choices one makes, whether good or bad, define the type of life an individual lives. This, thus, resonates with the theory of utilitarianism, which 'is a normative ethical theory that places the locus of 
right and wrong solely on the outcomes (consequences) of choosing one action or policy over other actions or policies' (Cavalier n.d).

The religious creativity and dexterity with which the movement has translated its relevance particularly in a world where there is abject poverty is worth acknowledging. The focal point of the prosperity gospel is that God blesses those who give generously and act in some liturgical format, which the preachers teach are based on a literal understanding and application of scriptures. Some of the common strands of emphasis include wealth, health, success and ever-soaring profits in business. These are coveted, cherished and perceived by the leaders of this movement and their adherents as signs of God's favour or as one of the genuine marks of sonship and faith in Christ. Some of the popular scriptures used by proponents of the prosperity gospel include 3 John 2; Genesis 13:2; Galatians 3:14, Job 1:3-9. It is imperative to note that prosperity preachers define faith through a peculiar exegetical and hermeneutical approach. Through a combination of imagination, confession of the scriptures and naming and claiming, their desires are believed to be actualised.

Despite the transposable liturgical practices and the ability to infiltrate any cultural context the neo-Pentecostal movement encounters, the movement over the years has been blighted by some of its leaders involved in various moral and financial misdemeanours of huge proportions at times. Although the challenge of moral or financial indiscretion is not peculiar to the neo-Pentecostal movement alone, the penchant for opulence, flamboyance, materialism and quest for economic security of many of the leaders of this Christian tradition has been noted as its major pitfall (Aiyegboyin 2006; Heuser 2015; Perriman 2002). While, arguably, this type of shift from only heavenly good to earthly concentration provides the much required opportunity for African Pentecostal churches to respond to various social, economic and political realities that call for religious response, it also calls for ethical evaluation. Nevertheless, the lust after materialism seems to be of epic proportions among most neo-Pentecostal preachers in Africa. Ayantayo (2014) argues in the case of Nigeria, thus:

$[T]$ he fact is that the quest for prosperity has heightened the desire for materialism among many Nigerians. Materialism is the tendency to value material things like wealth, money, cars, properties, clothing, high profit in merchandise and bodily comfort too much, and the moral spiritual and intellectual too little or not at all. Materialism is not bad itself, but lust for it, which has made some to do away with morality in order to get prosperous. (p. 11)

The claim of divine blessings by prosperity preachers is characterised by pomp and pageantry with outright eisegesis, which is the interpretation of a text or some parts of it in a manner that leads to the introduction of the readers' conjectures, schemas or preconceptions into and onto the text. For instance, Asamoah-Gyadu (2019), berating the crass mentality of materialism and eisegesis, notes that prosperity preachers like Archbishop Bishop Duncan Williams, a protégé of the late Bishop Benson Idahosa, conclude that, 'Jesus wore designer robes' in reference to the reason for the casting of lots for Jesus's cloth after his crucifixion (Matt 27:33-36). However, according to the Roman custom, the cloth of the crucified person is within the right of the executioners to appropriate as Jewish law required that the person being crucified would be stripped naked.

Most African countries are secular states as enshrined by their constitutions. The role of the state in regulating the religious space is largely anathema to many religious adherents including African Pentecostals; there is a dearth of intentional commitment to a life of integrity, accountability to their congregation as well as God. Because of the nonexistence of statutory or governmental agencies in most African states for regulating religious organisations like in developed countries such as the United Kingdom and the United States, the onus rests on African Pentecostal leaders to exercise probity, exhibit integrity and accountability, and live an incarnational lifestyle that is devoid of obsession with materialism. Obadare (2018) in his book, Pentecostal Republic, provides a detailed exposé on the flourishing relationship between the politicians and the Nigerian Pentecostals, and the obsession with power and materialism of some Nigerian neo-Pentecostal leaders. The endemic corruption and obsession with 'contemporary sale of indulgence' or sale of church position, criminal acquisition of wealth by religious leaders and deliberate suppression of the Bible truth from the people resonate with the challenges during the preReformation era. Although African Pentecostalism is growing numerically, it seems the hems of morality and spirituality are loose (Akhilomen 2018).

Interestingly, whether or not most African neo-Pentecostal church leaders have a sense of accountability for their membership or respective governing institutions, there seems to be a convergence in the affirmation of eschatopraxis. It is even observed that some neo-Pentecostal churches do not have state of faith: these churches merely shop for verses of the Bible that they feel suitable to rouse the emotion of their congregations. Contrarily, for instance, the statement of faith of Redeemed Christian Church of God (RCCG), which is perhaps the fastest growing Pentecostal denomination in sub-Saharan Africa, states that:

We believe that there will be three special judgments i) The Judgment of the Believers: This would start immediately believers are caught up in the sky, they shall stand before Christ. After this judgment they will descend down with Christ upon the earth - II Cor. 5:10; I Cor. 3:3; 11-15; James 1:12; Rom 2:16. ii) The Judgement of the Nation: This will be the time when Jesus appears upon earth between the millennial reign and final judgement. Acts 17:31; Joel 3:2; Ez. 14:15; Jud. 1:14-15; II Thess. 1:7-10; Rom 2:16; Rev. 1:7; Mal. 16:21. iii) The Judgement of the Unbelievers: or the White Throne Judgement: This will happen after Christ's one thousand years' reign at the White Throne. (Rv 20:11-15; Pt 2 3:7; Dn 12:2) 
The subscriptions to the supremacy of the Bible and many doctrinal positions on judgement, rapture and holiness raise a fundamental question as to whether some of the Pentecostal leaders will be exempted from the apocalyptic events. Although content analysis of sermons of African Pentecostal leaders is outside the purview of this study, the authors have noted that sermons on eschatological events are rarely preached by many African neo-Pentecostal pastors as the focus of their sermons is mostly on motivational talks couched with words of optimism, which are controversially rooted in the Christian theology. The obvious inference, thus, is that if the scriptures being proclaimed by African Pentecostal leaders are factual, it thus implies that they have failed to take cognisance that answerability and accountability are central to life after death. This is because the absence of teaching on accountability and eschatology has negative consequences on both secular and spiritual spaces. One of the consequences is the inveterate corruption in both spaces. Apostle Paul severally taught that accountability is inevitable for Christians and non-Christians as part of the apocalyptic events (Rm 14:12; Gl 6:1-5; Heb 4:13; Heb 13:17; 2 Cor 5:10). Not only did he note the above assertions of the apocalyptic events, Paul was equally prescriptive to the church on how to avoid the weight of the pending judgement, particularly to those who want to reign with Christ in the millennial dispensation. He noted in his letter to the church in Colosse that (Col 3:1-2, ESV):

If then you have been raised with Christ, seek the things that are above, where Christ is, seated at the right hand of God. Set your minds on things those are above, not on things that are on earth.

The blurring of ethical boundaries by some neo-African Pentecostal leaders raises fundamental questions about their Christian commitment and understanding of accountability within the lens of eschatology. If, indeed, eschatological events are true as many African Pentecostal leaders acknowledge in their statement of faith, then there is a huge moral responsibility not only placed by ecclesiastical structures but also a personal sense of responsibility by which actions are evaluated. The challenge to the neoPentecostal movement is that accountability is a constant demand from all who subscribe to any organisation - whether spiritual or secular. Essentially, there would be review of one's responsibility while alive. According to Braziel (2013):

[S]ince accountability is a fact of life, we are going to be accountable for the manner in which we lived our lives from the moment we accepted Jesus Christ until the day we died or the day the Lord returned to get us, whichever came first. (n.p.)

The review that would take place at the judgement would involve what Christians had done; a replay of how they did it as they are ipso facto workmen with God (Eph 2:10). Accountability would lead to refining by fire the works of every individual Christian. The quality of what each did would then be tested. Herein the materials used, six of them, as Paul mentioned, become important: 'gold, silver, precious stones, wood, hay, straw'. While the refining fire would purify the first three, it would char the last three. This gives the notion that it is not just the quantity of works that matters, but the quality as well (Braziel 2013).

But the point we intend to bring to focus is that eschatopraxis as being understood, related and deployed gives only one side of the coin, namely, that there might be no final judgement; that heaven is secured for all Christians (irrespective of how they live after accepting Christ); and that the bliss of heaven must be enjoyed here as a foretaste. Ironically, we posit that some African neo-Pentecostal leaders have adopted a pick and mix model, which is characteristic of the postmodern mindset in terms of their decision to enjoy a blissful life on earth without any sense of accountability here on earth believing that the final judgement might be a mirage or that God can be appeased with money and earthly acquisitions to escape his ultimate judgement (Igboin 2017).

\section{Conclusion}

We have argued that life matters and death matters to anyone who subscribes to Christianity as his or her faith. That life and death matter is important for the simple reason that while it has eschatological relevance, it is grounded on age-long Christian ethical predicates and demand. Eschatology is about ethics and morality upon which actions are reviewed in the immediate and ultimate time. This then means that eschatology is about accountability, and accountability does not exempt any part of human actions. Given this, we argued that though there is a pervasive despondency among the citizens of many African countries caused by the failure of the state, neo-Pentecostal social interventions are not excluded from moral scrutiny. We paid particular attention to the neo-Pentecostal movement that emphasises that prosperity is the hallmark of genuine Christianity. This brand of Christianity teaches that heaven can be enjoyed on earth fully, a wrong interpretation and application of eschato-praxis. The fact that eschato-praxis emphasises actions to better the world does not mean that ethics and accountability both at immediate and ultimate levels should be discountenanced. Rather eschato-praxis demands that Christians have ethical and practical responsibility towards making the world a better place for all. It is therefore not a strategy by leaders to exploit members and live extravagantly as it presently appears in many neo-Pentecostal churches. Eschato-praxis collapses into eschatology, and then accountability becomes not only an immediate demand but also an ultimate responsibility. Realising this would help neoPentecostal movement to reappraise its teaching and practice with regard to eschato-praxis and ultimate accountability before God.

\section{Acknowledgements Competing interests}

The authors have declared that no competing interests exist. 


\section{Authors' contributions}

B.O.I. was responsible for the conceptualisation of life and death matters and engaging the concept of eschato-praxis. The two authors jointly contributed to the section on 'Accountability in theological-eschatological prism', while B.A.A. using sociological approaches situated the discourse within African Pentecostalism and prosperity gospel within the purview of accountability in relation to eschatology. This presents a reflective discourse with respect to the urgent need for reassessment of the praxis of African Pentecostals as accountability is inevitable in matters of life and death.

\section{Ethical considerations}

This article followed all ethical standards for research without direct contact with human or animal subjects.

\section{Funding information}

This research received no specific grant from any funding agency in the public, commercial, or not-for-profit sectors.

\section{Data availability statement}

Data sharing is not applicable to this article as no new data were created or analysed in this study.

\section{Disclaimer}

The views and opinions expressed in this article are those of the author(s) and do not necessarily reflect the official policy or position of any affiliated agency of the authors.

\section{References}

Adedibu, B., 2013, 'Origin, migration, globalisation and missionary encounter of Britain Black Majority Churches', Studies in World Christianity 17(1), 93-113. https://doi.org/10.3366/swc.2013.0040

Adedibu, B., 2018, 'Corruption conundrum: A call for awakening of the prophetic voice of Nigerian Pentecostal church leadership', in B.O. Igboin (ed.), Corruption: A new thinking in the reverse order, Crowther University Press, Oyo, Ajayi.

Adogame, A., 2014, 'Doing things on earth for heaven's sake', Faculty of Arts Public Lecture, Adekunle Ajasin University, Akungba-Akoko, Nigeria, 20th February.

Aiyegboyin, D., 2006, 'A rethinking on prosperity teaching in the new Pentecostal churches in Nigeria', Black Theology 4(1), 70-86. https://doi.org/10.1558/blth 2006.4.1.70

Akhilomen, D., 2018, 'The church on earth and the quest for heaven: Gleanings from Salient Church Historical experiences', 70th inaugural lecture, Ambrose All University, Ekpoma, Edo State, Nigeria, 26th April.

Anderson, A., 1999, 'Global Pentecostalism in the new millennium', in A. Anderson \& W.J. Hollenwenger (eds.), Pentecostals after a century: Global perspectives on a movement in transition, Sheffield Academic Press, Sheffield.

Asamoah-Gyadu, K., 2013, Contemporary Pentecostal Christianity, WIPF \& Stock, Eugene, OR.

Asamoah-Gyadu, K., 2019, 'Did Jesus wear designer robes?' Christianity Today, viewed 27 February 2019, from https://www.christianitytoday.com/ct/2009/november/ main.html.

Ayantayo, K., 2014, 'Prosperity gospel and social morality: A critique in Ogungbile', in David \& A. Akinade (eds.), Creativity and change in Nigerian Christianity, Malthouse, Lagos.

Braaten, C.E., 2000, Eschatology and ethics, Augsburg, Minneapolis, MN.
Braziel, R.A., 2013, 'Accountable to God', Christian Hope Church of Christ, Plymouth, NC, viewed 03 November 2013, from https://christianhopechurch.com.

Cavalier, R., n.d., Online guide to ethics and moral philosophy: Utilitarianism theories, viewed 16 February 2019, from http://caae.phil.cmu.edu/cavalier/80130/part2/ sect9.html.

Chimhanda, F.H., Molobi, V.M.S. \& Mothoagae, I.D. (eds.), 2015, African theological reflections: Critical voices on liberation, leadership, gender and eco-justice, UNISA Pretoria.

Cone, J., 1970, A black theology of liberation, Lippincott, Philadelphia, PA.

Cooper, P.R., 2017, 'Poor, wayfaring stranger: Erik Peterson's apocalyptic and public witness against Christian Embourgoisement', Religions 8, 45. https://doi.org/ 10.3390/rel8040045

De Gruchy, J.W., 2002, Reconciliation: Restoring justice, Fortress Press, Minneapolis, MN.

Dussel, E., 1988, Ethics and community, transl. R.R. Barr, Orbis Books, Maryknoll, New York.

Eagleson, J. \& Drury, J. (eds.), 1975, Christians and socialism: The Christian for Socialism Movement in Latin America, Orbis Books, New York.

Gbote, E.Z.M. \& Kgatla, S.T., 2014, 'Prosperity gospel: A missiological assessment', HTS Teologiese Studies/Theological Studies 70(1), Art. \#2105, 1-10.

Gutierrez, 1973, A theology of liberation: History, politics and salvation, transl. C. Inda \& John, Orbis Books, New York.

Hebert, D., n.d., 'The need for teaching the eschatological gospel of both comings of Jesus Christ in the 21st Century especially if we see the day of his Parousia approaching', viewed 16 June 2018, from http://hdl.handle.net/10500/3180.

Heuser, A. (ed.), 2015, Pastures of plenty: Tracing religio-scapes of prosperity gospel in Africa and beyond, studies in the intercultural history of Christianity, vol. 161, Peter Lang, Frankfurt am Main.

Igboin, B.O., 2017, 'Thus says the lord, thou shall not fight corruption', paper presented at the 38th Nigerian Association for the Study of Religions (NASR) held at Adeleke University, Ede, Osun State, Nigeria, 11-14th September.

Igboin, B.O., 2018a, 'The theological and moral economy of corruption', in B.O. Igboin (ed.), Corruption: A new thinking in the reverse order, Ajayi Crowther University Press, Oyo.

Igboin, B.O., 2018b, 'Morals and Values in Christianity as precursors for sustainable church growth in Nigeria' Keynote Address delivered at the 2018 Week of Spiritual Emphasis organized by the Christ Apostolic Church Theological Seminary, Idimu, Lagos, 19th May.

Jenkins, P., 2006, The new faces of Christianity: Believing the Bible in the Global South, Oxford University Press, New York.

Johnson, T.M., Zurlo, G.A., Hickman, A.W. \& Crossing, P.F., 2017, 'Christianity 2018: More African Christians and counting martyrs', International Bulletin of Mission Research 42(1), 20-28.

Jones, D.W. \& Woodbridge R.S., 2011, Health, wealth and happiness: Has the prosperity gospel over shadowed the gospel of Christ?, Kregel, Grand Rapids, MI.

Kant, I., 1956, Critique of practical reason, transl. L.W. Beck, Bobbs-Merrill, New York.

Levinas, E.L., 1969, Totality and infinity, transl. A. Lingis, Duquesne University Press, Pittsburgh, CA.

Levinas, E.L., 1988, Collected philosophical papers, transl. A. Lingis, Duquesne University Press, Pittsburgh, CA.

Martin, G.T., 2019, Ethics and eschatology: Transforming the world's war system to a world peace system founding a global social context, viewed 25 February 2019, from https://www.radford.edu/gmartin/Ethics. Eschatology.War.Peace. GTM.2.Feb13.pdf 7 .

Obadare, E., 2018, Pentecostal republic: Religion and the struggle for state power in Nigeria, Zed Publisher, London.

Oketch, B. \& Ebong, P. (2017), 'Man buried with Shs200m bribe for God', Daily Monitor, viewed 26 June 2019, from https://mobile.monitor.co.ug/News/Officer-buriedShs200m-bribe-God/2466686-3511412-formart-xhtml-wso1m0z/index.html.

Perriman, (ed.), 2002, Faith: Health and prosperity. A report on word of faith and positive confession, Paternoster Press, Carlisle.

Peters, T., 2000, God - The world's future: Systematic theology for a new era, 2nd edn., Fortress Press, Minneapolis, MN.

Platt, D., 2010, Radical: Taking back your faith from the American dream, Multinomah Books, Colorado Springs, CO.

Sands, J., 2017, 'Introduction to 'In anticipation: Eschatology and transcendence in contemporary contexts', Religions 8, 1-6.

Segundo, J.L., 1975, The liberation of theology, Orbis Books, Gustavo, New York.

Shoemaker, D., 2011, 'Attributability, answerability, and accountability: Toward a wider theory of moral responsibility', Ethics 121, 603-632. https://doi.org/10.1086/659003

Smith, A.M., 2012, 'Attributability, answerability, and accountability: In defense of a unified account', Ethics 122(3), 575-589. https://doi.org/10.1086/664752

Walls, A., 2000, 'The gospel as prisoner and liberator of culture,' cited in A.J. Gittins, 'Life and death matters', Life and death matters: The practice of inculturation in Africa, Steyler Verlag, Nettetal. 